\title{
NISCH wt Allele
}

National Cancer Institute

\section{Source}

National Cancer Institute. NISCH wt Allele. NCI Thesaurus. Code C101382.

Human NISCH wild-type allele is located in the vicinity of 3p21.1 and is approximately 38 $\mathrm{kb}$ in length. This allele, which encodes nischarin protein, plays a role in imidazolinemediated signaling. 